\title{
Bringing Students Closer to the World of Work through the School of Industrial Culture Implementation (SIBI) at State Vocational School of Mandiraja 1, Banjarnegara
}

\author{
N Fatimah ${ }^{1}$, A Luthfi ${ }^{2}$, and I H N Utari ${ }^{3}$ \\ ${ }^{1,2,3}$ Department of Sociology and Anthropology, Universitas Negeri Semarang \\ \{1 fatimahnurul8@mail.unnes.ac.id\}
}

\begin{abstract}
Abstract. This paper discusses about the implementation of the School of Industrial Culture Implementation (SIBI) program at State Vocational School of Mandiraja 1. SIBI is a new effort was implemented by schools aimed at bringing students closer to the world of work. There are 3 main activities in the program including the adaptation of internship, preparedness and habituation programs through the 5R (Ringkas/ Concise, Rapi/ Neat, Resik /Clean, Rawat/ Care and Rajin/ Diligent). This study aims to find out how the application of SIBI and the obstacles faced in developing the program. This study uses a qualitative method. The phenomenon in this study was analyzed using Pierre Bourdieu's habitus theory and cultural concepts. The results showed that the SIBI program had been applied well to several aspects of activities and habits of industrial culture through habituation of $5 \mathrm{R}$ and adaptation had begun to be embedded in students even though it was still partial (because the culture in question had not touched all students there were students who committed violation ). However, if viewed from the concept of culture, the SIBI in Mandiraja is still pseudo because the form of industrial culture is actually not as simple as that applied through the SIBI program. Constraints faced in implementing the SIBI program include the difficulty of finding partner industries, no clear sanctions for SIBI program violators, teacher commitment, lack of facilities and infrastructure, too many students, and responses from less enthusiastic students.
\end{abstract}

Keywords: Adaptation of Internship, Habituation of 5R, Preparedness, SIBI

\section{INTRODUCTION}

Education is a human effort to foster his personality to fit the values and norms that exist and apply in society. Education aims to form a dignified nation's character and civilization in order to educate the nation's life. [1] revealed the development of national character values can be achieved if the learning process in schools is not only knowledge transfer (educational process), but also includes the transfer of values life.

Along with the time progress, education can be used to gain profits and even put education as one form of commodity. The development of educational goals makes the government and society think of various efforts to meet market needs, even though basically true education is not a commodity. [2]states that school as a center of education must be separated from capitalism culture which is only oriented to material benefits, so that six pillars of education 
can be achieved, namely: Learning To Know, Learning to Do, Learning to Live Together, Learning to Be, Learning how to learn, learn

throughtout life.

One of the demands of the globalization era was marked by the strengthening of free market understanding. [3] that the presence of the Asean Economic Community (MEA) in 2016, caused more competition to occur in the looking for jobs. This competition is caused by the small number of jobs, while the number of job seekers is increasingly abundant, coupled with the arrival of people from other ASEAN countries entering Indonesia. Such a situation then forces the community to prepare themselves to be able to work and explore their potential to be able to get a job. [4]which states that effective changes in students including characteristics are examined in vocational school education interventions. In order to respond to the government's concerns about the existence of a free market that will have an impact on the economic inequality of the community, the government has formed a state vocational school in various regions in Indonesia. In the hope that there will be a generation that is ready to work and can compete with the international world, where the school adapts to the potential of the region. Supported by the demands of the era of 4.0 that require a lot of leaps and accelerations in the development of a program that not only runs on the right track [5].

Vocational schools not only prioritize the learning process in schools but also output or graduates. Students who have graduated will be expected to be able to work in accordance with their fields without having to go through the higher education level first. [6] in addition to working in the field of generation in era 4.0 must be very adaptive and multi-tasking by having a high mastery of IBT. Unfortunately the strategic role of Vocational Schools has not been maximally carried out, there are still many vocational school graduates who are not competent with the needs of the workforce. [7] states that the number of vocational education in the UK has not yet linked the curriculum to market needs, both in the world of work and universities. Vocational education is still more quantity-oriented, not yet on the quality needed.

At present many people are uneducated or only through non-formal education but it is easier to get a job compared to people who are highly educated. This happens because ordinary people (who do not have formal education) rely more on their skills or skills while those who are highly educated (formal) but are not balanced with skills so many scholars who do not get jobs or are unemployed.) [8]states that globalization is being and continues to increase competition in various fields, including the employment sector. In a situation like this comparative advantage is not enough, it also requires competitive labor that will enter labor market competition. In addition, the ability of graduates from training and education activities pursued in vocational schools contributes positively to the ability of business innovation and production in the company [9]. This shows how strategic the role of vocational school is in developing the world of industry.

In vocational schools in general also carry out cooperation with the business world / industrial world but has not been accompanied by the development of industrial culture. In addition to industrial partnerships, vocational schools must begin to establish partnerships with the community.[10] vocational schools must have networks and partnerships with the community either through community schools or other forms of education, this is intended to create a harmonious situation between the world of education and the needs of the community. Various efforts were made by vocational schools to prepare alumni to be ready to face the world of work. [11] emphasizes the importance of self-improvement as a form of preparation to face the increasingly stringent challenges of the world of work for vocational schools in particular. 
Whereas in the Mandiraja State Vocational School in addition to cooperating with the business world/industrial world, in reality it succeeded in instilling industrial culture with its students because it was accompanied by the application of industrial culture programs which were later termed the School of Industrial Culture Implementation (SIBI). [12] that skills must be mastered by the community, especially students from an early age. As a school with the implementation of industrial culture, the school prioritizes students to get lessons, skills, practices and also jobs after graduating later in accordance with the chosen department related to today's industry. With this excellent program there is something interesting to be investigated further, namely how the implementation of the School of Industrial Culture Implementation program will be abbreviated as SIBI at Mandiraja State Vocational School 1, Banjarnegara Regency.

\subsection{Research Method}

This study uses a qualitative approach. [13] define qualitative methods as research procedures that produce descriptive data in the form of written or oral words from people and observable behavior. The location in this study was in Mandiraja State Vocatinal School 1, where the school had ideas and implemented the SIBI program. The main informants in this study were the Principal, Deputy Principal in the curriculum field, and the XI grade Students of the Mandiraja State Vocational School. Supporting informants in this study were administrative staff. Data collection in this study using observation, interviews, and documentation. Tests of data validity using data triangulation techniques. Data analysis techniques include data collection, data reduction, data presentation and verification or conclusion. There are several obstacles that hinder research activities. These constraints are in the form of a research schedule that collides.

\subsection{Result and Discussion}

The SIBI program is a school effort to apply industrial culture to students. [14] an interesting industrial culture developed is by combining the local culture indigenous and culture that develops in general. This means that the local culture indigenous becomes a part that must be considered. [15] has a link between the development of a learning culture with the climate change industry. An industrial world that is initially more output oriented, needs to start developing a learning culture as a process to get better quality output.

Before the SIBI program was implemented in Mandiraja State Vocational School 1, planning was carried out in advance so that the program could run smoothly as expected. Planning is done to find out the various potentials that make it possible to be appointed as a program. [16] a lot of things that can be explored become a potential to develop a good vocational school which is considered entirely new and even already used but can still be developed.

The program is carried out continuously in schools which consist of activities in the classroom, outside the classroom and through special program activities. Where activities in the classroom include 5R (Ringkas/ Concise, Rapi/ Neat, Resik /Clean, Rawat/ Care and Rajin/ Diligent), activities outside the classroom include extracurricular and clean environment, as well as special programs that include preparedness and adaptation of internship. SIBI is used as a tool used by schools to realize its vision and mission.

The $5 \mathrm{R}$ activities in the class are held during the first hour and the last hour of school lessons. Although in reality many are out of synchronous between what informants say and 
conditions in the field. It turns out that $5 \mathrm{R}$ activities in the last lesson are often passed by subject teachers. Besides that the $5 \mathrm{R}$ concept doesn't all work well in every class. This is due to the low awareness of students about the importance of maintaining these $5 \mathrm{R}$ values. $5 \mathrm{R}$ was adopted from the 5S concept in Japanese companies, namely Seiri, Seiton, Seiso, Seiketsu, Shitsuke which then became 5R. The 5R concept is then entrenched in the industrial world to support the creation of a good level of efficiency and productivity in a company.

The $5 \mathrm{R}$ activity carried out in the classroom also took place in vocational practice activities. Activity $5 \mathrm{R}$ is carried out after the practice is completed, namely by cleaning the workplace, cleaning the equipment that has been used, storing the machines or practical tools in their place again, cleaning up the garbage around the place practice, maintain school facilities, and close the practice room window after use. The activity takes place in every department at Mandiraja State Vocational School 1 when carrying out practical learning in the classroom.

The SIBI program stated in activities outside the classroom is on extracurricular activities and healthy walking / clean environment. Extracurricular activities are very important to be carried out in an educational institution because with the existence of extracurricular activities, it will balance between the knowledge of the subject matter were gets in the classroom and also develop his talents, interests and potentials. Mandiraja State Vocational School 1 provides a number of extracurricular activities that can be freely chosen by students according to their interests. On extracurricular activities that are routinely held once a week also requires the activities to carry out $5 \mathrm{R}$.

Furthermore, for a healthy environment / clean road activities carried out every Friday the last week, which was attended by all students and teachers. In addition to activities related to physical fitness of students in preparing themselves to face the industrial world, 5R activities are also implemented there. Sometimes the activities of Friday in the last month were carried out with joint exercise, cleaning waterways, cleaning the river and cleaning the surrounding environment. Thus, students are expected not to be saturated with their routes every month because there are interlude clean environment activities that are no less beneficial for students.

The Preparedness Program. UIn the special programs consist of preparedness and adaptation of internship. Preparedness is a physical test whose main activities include running around the field, $12 \mathrm{k}$ m running, pull-ups, sit-ups, push-ups, and shuttle-runs that are carried out to measure students' physical abilities each year. In addition there are also other tests such as checking blood pressure, height, weight, eye tests and interspersed with games. The school works with the Mandiraja sub-district military command to conduct medical tests as well as mental training or leadership training. Students will stay for two days and nights at the Indonesian National Army (TNI) headquarters and carry out activities there including religious activities. The school realized that to enter the industrial world, students were not only smart enough but also good character and also good physical condition. It can even be said that there is no large industry that does not carry out medical tests or medical check up in the recruitment of their employees. Students who will later be declared graduated will apply to work in the industry, so students will face several health tests such as color blindness tests or eye tests, urine tests, height tests, heart tests, blood pressure tests, and so on. So the school has introduce and prepare students since they are in school to maintain their physical fitness and check their health condition so that they will know what should be improved or improved when there is something they feel is lacking and what has met the standards.

Adaptation of Internship Program. There are two stages of students in carrying out the adaptation of internship, namely following training in internship and also the implementation of the internship. Adaptation of internship is a bridge between schools and the industrial 
world. Before students go directly into the industrial world, students will be provided with useful material and become a benchmark when implementing internship. The main debriefing will be carried out internally from the school, namely from the teachers appointed by the principal. The school also initiated the provision of other internship carried out by the pairing industry, but for this year it has not been able to bring in all the industry partners and just carried out debriefing from Surya Yudha Bank. The implementation of internship is carried out for 3 until 6 months. The implementation mechanism uses two ways, namely determined by the school and selects the industry of interest. The school success in implementing the actual SIBI program can also be seen in the implementation of internship. Where in the internship of students will be faced with the real world about industry and industrial culture, students will be trained to work in industries that apply the same rules as the contents of the SIBI program which has been applied at the school and is no stranger to students. The adaptation of internship will certainly form a mutually beneficial collaboration. The points of the SIBI program that are applied every day starting to be embedded within students are not entirely from their desires and self-awareness. There are some students who find it difficult to follow school rules then become obedient to school rules including following the SIBI program points because of fear of teachers watching over them. The existence of the SIBI program in Mandiraja State Vocational School will instill habits about good things for students in facing the industrial world later, so that they have an understanding of the world of industry and can apply good attitudes or character in accordance with what is needed by the industry.

Evaluation was carried out to determine the success of the implementation of the SIBI program that was implemented in Mandiraja State Vocational School 1. Evaluation activities are carried out in the long and short term. Evaluation in the short term is done by observing students when in the school environment. For students who are known to disobey the SIBI rules, they are motivated from time to time so they don't break again. This activity is very important because it gives the impression to students that they are always considered by the school and are always reminded of the industrial culture, so that they are reluctant to commit violations again.

[17]says that actors or individuals are equipped with a series of schemes or patterns that are internalized into themselves, which are then used to feel, understand, realize and assess the social world which will then create habitus. Mandiraja State Vocational School 1 as a vocational school that implements the SIBI program, is an arena that is deliberately formed to form the habitus of industrial culture with the target of its students. The school is tasked with preparing and implementing the SIBI program, with the aim of forming capital and influencing the actions of agents / actors, namely students of Mandiraja State Vocational School 1. Furthermore, students will carry out activities related to the SIBI program that have been prepared in advance by the school.

The SIBI program has been applied continuously in schools with the aim of its students and students will learn to understand the industrial culture introduced by the school so that it will form a culture. Although in reality, the implementation of the SIBI program turned out to only extend to the second form of culture and not yet reached the third form, namely objects produced by humans. Mandiraja State Vocational School 1 in implementing the SIBI program has not been perfect to the third form of culture according to Koentjaraningrat even though all three should be interrelated to create a culture. In addition, culture is an act or human activity that is carried out automatically because it has stuck in his mind, but there are students who violate the rules by not carrying out SIBI activities so that the existing culture in SIBI in Mandiraja Stae Vocational School is still pseudo. 


\section{CONCLUSIONS}

The SIBI program is an idea or work from the school that is intentionally designed to form the habitual or habitual habits of students about industrial culture at the Mandiraja State Vocational School 1 in Banjarnegara Regency. Seen from 3 stages, namely planning, implementation, and evaluation. In the planning stage, carried out from the formulation of ideas and socialization to teachers and students. The SIBI program implementation phase consists of three activities, namely activities in the class consisting of, activities outside the class consisting of extracurricular and healthy / clean roads, special program that consists of preparadness and adaptation of internship (briefing on internship and implementation of internship). SIBI program evaluations are conducted in the short term every week and long term by the school at the end of each semester. Constraints faced in implementing the SIBI program are the difficulty of finding partner industries during SIBI formulation, the commitment of teachers to run the SIBI program, there are no strict sanctions for students who do not obey the SIBI program, the number of students is too much, and the lack of facilities and infrastructure. In addition, obstacles also arise from students who are not obedient in running the SIBI program.

\section{REFERENCE}

[1] P. Astuti, Kismini, "The Socialization Model of national Character Education for Students in Elementary School Through ComicNo Title," KOMUNITAS Int. J. Indones. Soc. Cult., vol. 6, no. 2, p. 260-270., 2014.

[2] M. Solihin, "Kapitalisme Pendidikan (Analisis Dampaknya Terhadap Upaya Mencerdaskan Kehidupan Bangsa)"," J. Pendidik. dan Sos. Keagamaan, vol. 2, no. 2, 2015.

[3] A. Hidayati, "Relevansi Kompetensi Lulusan Sekolah Menengah Kejuruan dengan Kebutuhan Dunia Usaha dan Industri (Studi Kasus di SMK Negeri 1 Batang)," Pros. Semin. Pendidik. Ekon. dan Bisnis jurnal.fkip.uns.ac.id, vol. 1, no. 1, 2015.

[4] K. Friberg, An Educational-Vocational Intervention: Through a Work-Life Orientation Program in Finnish Comprehensive Schools. SAGE, 2013.

[5] Y. and Qin, "A smart performance measurement approach for collaborative design in Industry 4.0," Adv. Mech. Eng. DOI 10.1177/1687814018822570. journals.sagepub.com/home/ade, vol. 11, no. 1, pp. 1-15, 2019.

[6] M. and K. Roblek, "A Complex View of Industry 4.0.," SAGE Open DOI 10.1177/2158244016653987. sgo.sagepub.com, no. April-June, pp. 1-11, 2016.

[7] R. Patel, "Are we there yet? Vocational education at crossroads," Local Econ. sagepub.co.uk/journalsPermissions.nav. DOI lec.sagepub.com, vol. 27, no. 3, pp. 227-231, 2012.

[8] Yoto., "Meningkatkan Mutu Pendidikan Kejuruan Melalui Program SMK Unggulan," J. Pendidik. Prof., vol. 2, no. 1, 2013.

[9] P. Toner, "Innovation and Vocational Education," Econ. Labour Relations Rev. Cent. Innov. Ind. Stud. Univ. West. Sydney, vol. 21, no. 2, p. .75-98, 2005.

[10] C. Kreber, "Transforming Employment-Oriented Adult Education to Foster Arendtian Action: Rebuilding Bridges Between Community and Vocational Education," Adult Educ. Quarterly. Adult Contin. Educ. sagepub.com/journalsPermissions.nav. DOI10.1177/0741713614566674. aeq.sagepub.com, vol. 65, no. 2, p. 100-115., 2015. 
[11] L. and F. Guy, Sitlington, "What Are High Schools Offering as Preparation for Employment? Career Development for Exceptional Individuals.," Hammill Inst. Disabil. 10.1177/0885728808318625 http//cdei.sagepub.com hosted http//online.sagepub.com, vol. 32, no. Mei, pp. 30-41, 2009.

[12] F. dan R. Pradana, "Pelaksanaan Gerakan Literasi Sekolah sebagai Upaya Membentuk Habitus Literasi Siswa Di SMA Negeri 4 Magelang,” J. Solidar., vol. 6, no. 2, pp. 167 179, 2017.

[13] L. J. Moleong, Metodologi Penelitian Kualitatif, Edisi Revi. Bandung: PT. Remaja Posdakarya, 2007.

[14] M. and Marais, "Walking between worlds An exploration of the interface between indigenous and first-world industrialized culture," Int. Soc. Work. Sage Publ. Los Angeles, London, vol. 50, no. 6, pp. 809-820, 2000.

[15] Dymock, "Developing a Culture of Learning in a Changing Industrial Climate: An Australian Case Study," Adv. Dev. Hum. Resour. DOI 10.1177/1523422303251367. Copyr. 2003 Sage Publ., vol. 5, no. 2 May, pp. 182-195, 2003.

[16] M. and M. Flores, Martinez, "Something Old and Something New: Future Directions in Vocational Research With People of Color in the United States," J. Career Assessment. sagepub.com/journals-permissions DOI 10.1177/1069072718822461. journals.sagepub.com/home/jca, pp. 1-22, 2019.

[17] R. and Douglas, Teori Sosiologi Modern, Edisi Keen. Jakarta: Kencana, 2005. 